\title{
PSYCHE.
}

\author{
NOTES ON THE ACRIDIDAE OF NEW ENGLAND.-II.-TRYX- \\ ALINAE.- VI. \\ BY ALBERT P. MORSE, WELLESLEY, MASS.
}

\section{Chloealtis Harr.}

Chloealtis Harris $184 \mathrm{r}$. Report $\mathrm{p}$. 148. 3rd ed., r862, p. 184 .

This genus was established by Harris on two species of which one (curtipennis) belongs to Stenobothrus (Fischer, I853), the other (conspersa) must receive this name. Chrysochraon (Fischer, I853) is closely related, especially Ch. dispar of Europe, but if but one name can.be retained that must be Chloealtis which has twelve years priority. In Brunner's Revision this generic title is evidently applied to the species hitherto known as Ch. viridis; here treated under the title of Dichromorpha.

\section{Chloealtis conspersa Harr.} Figs. I I, I Ia.

Chloealtis conspersa. Harris $\mathrm{I} 84 \mathrm{I}$. Report, I49; ed. I862, p. I84. Scudder, 455. Fernald, 36. Smith, Me., I45; Conn., 375. Morse, I3, I04. Beutenmüller, 293 .

Chloealtis abortiva Harris, 149 ; ed. I862, I 84 .

Chrysochraon conspersum. Thomas, 76. Comstock, IO2.

Stenobothrus melanopleurus. Scudder, $45^{6}$.
This species is readily recognized by the absence of foveolae, the shining black sides of the pronotum of the male, and the peculiar form of the ovipositor of the female. The male differs so much in size and appearance from the female that it was described as a Stenobothrus (melanopleurus) by Scudder. The $\delta$ varies from pale straw to dark brown, but is usually light brown above, and the tegmina immaculate, sometimes with very faint dusky spots; the hind tibiae are either red or yellowish. The $q$ varies from straw to very dark fuscous brown, and usually has the tegmina more or less spotted with dusky, though they are sometimes immaculate. The name abortiva Harris does not seem worthy of retention, far the larger number of specimens being intermediate in markings.

About 350 specimens, nearly onehalf of which are females, give the following measurements :

$$
\begin{array}{ccccc}
\text { Antenna. } & \text { Hind fem. } & \text { Teg. } & \text { Teg. }<\text { Hind fem. } & \text { Body. } \\
\delta^{*} \text { 10-11 } & \text { ro.7-13 } & 7 \cdot 7-12 & 3-5 \cdot 5 & 15-19 \\
\text { 10-12 } & \text { 1r.6-16 } & 7-10 & 8-11 & 20-28
\end{array}
$$

The wings in the male are usually one-third to one-half, in the female onehalf to two-thirds, as long as the tegmina. In the female the abdomen 
about reaches the tip of the hind femora, in the male it falls short by 2 to $4 \mathrm{~mm}$.

$\mathrm{McNeill}$ was the first to announce the occurrence of long-winged individuals in this species in Illinois; Blatchley captured a female in Indiana, and last season I secured two in Sherborn, Mass. I have not seen a male with functional wings. This form may be distinguished as prima. These two females measure as follows :

Tegmina. Wing. Teg. $>$ Hind fem. Total length.
Long. Wide. Long. Wide. I9. $5 \quad 4.7 \quad 18 \quad-8.5$

$\begin{array}{llllll}19.5 & 4.7 & 18 & 8.5 & 2 & 27 \\ 20 & 4.8 & 18 & 8.5 & 3 & 28\end{array}$

While not abundant, this species is common locally in suitable situations. It seems to prefer bushy pastures or edges of pine woods but is found wherever old stumps or fragments of soft or decaying wood are accessible as a nidus for its eggs. I have several times found it associated in locality with Ps. brachyptera and Mel. "rectus," with the one in bunch-grass, with the other in low bushes, etc., in both cases in close proximity to woodland. The females are rather sluggish and easily captured, moving of necessity by crawling and leaping, but the males are quite alert and active.

It may be found from the latter part of June throughout the season. I have taken the adult $\delta$ on June 24 , and the $q$ on Oct. 7. I have collected specimens at Deering, Fryeburg, Norway, and Stoneham, Me. ; No. Conway, summit of Kearsarge Mt., and Jackson, N. H. ; Hyde Park, Jay, and St. Johns- bury, Vt. ; Wellesley and several towns in its vicinity, Winchendon, Wood's Holl, and West Chop, M. V., Mass.; Wickford, R. I.; Canaan, Montville, New Haven, Niantic, and Stamford, Conn.

An interesting account of its oviposition is given in Smith's Orthoptera of Maine (also Orth. of Conn.) and, together with additional matter, in Scudder's Distribution of Insects in $\mathrm{New}$ Hampshire. The latter work contains a description and notation of its songs in sunshine and shadow, which may also be found in the 23rd annual report of the Entomological Society of Ontario.

9. Stenobothrus Fisch.

Stenobothrus Fischer, 1853. Orth. europ., p. 3 I3.

12. Stenobothrus curtipennis Harr. Fig. I 2 .

Locusta (Chloealtis) curtipennis. Harris, Rep't, 149, 184I ; ed. 1862, I 84 .

Stenobothrus curtipennis. Scudder. 456. Thomas, 9r. Smith, Orth. Me., I47. Fernald, 37. Morse, 14, I04. Beutenmüller, 294.

Long-winged form, longipennis.

Stenobothrus longipennis. Scudder, $457, \quad \mathrm{r} 862 .=$ var. of curtipennis. Smith, Thomas, Morse, cit. supra.

This species is the only true Stenobothrus occurring in New England, and, while one of the most variable of our locusts in color, markings and wing- 
development, is readily recognized by the presence of foveolae visible from above. The length of tegmina and wings is very variable and consequently of very slight importance, several marked color varieties being either long or short winged. The wings, while often very small, are probably always capable of being expanded sufficiently to serve as parachutes at least, being in nearly every case almost as long as the tegmina, not abortive as in Chl. conspersa. While the larger proportion of individuals captured fall into one of two series, being either long or short winged, no sharp line of demarcation exists between the series. In the short-winged the tegmina of the $\delta$ usually do not reach the end of the hind femora by 2 to $3 \mathrm{~mm}$., in the $?$ by 3 to $5 \mathrm{~mm}$.; in the long-winged they equal or exceed the femora $\mathrm{I}$ to $2 \mathrm{~mm}$., but intermediate examples are not uncommon. Short-winged individuals are somewhat the more numerous. The three most striking color varieties are the following: (I) dorsal half of sides of pronotum and cheeks fuscous, darkest above; (2) sides of pronotum gray, crossed halfway down by a broad, irregular, fuscous band; cheeks somewhat infuscated above and below a pale band at level of lower margin of eye ; (3) face, sides of head and body green. Each of these forms may be either long or short winged, light gray, yellowish, reddish, or fuscous above, or of intermediate shade.

\begin{tabular}{|c|c|c|c|}
\hline $\begin{array}{l}\text { Antenna. } \\
o^{*} 8.5^{-10.5} \\
\text { \& } 6.5^{-8}\end{array}$ & $\begin{array}{l}\text { H. fem. } \\
\text { Io. } 5^{-I x .8} \\
\text { II. } 5^{-14}\end{array}$ & $\begin{array}{l}\text { Teg. } \\
8.5^{-15} \\
7-16.5\end{array}$ & $\begin{array}{c}\text { Teg. vs. H. fem. } \\
\begin{array}{c}-3-+3 \\
-7^{-}+2\end{array}\end{array}$ \\
\hline & $\begin{array}{c}\text { Body. } \\
13 \cdot 5-15 \cdot 5 \\
15-24.5\end{array}$ & $\begin{array}{l}\text { Total. } \\
14-22\end{array}$ & \\
\hline
\end{tabular}

This is a sprightly, wide-awake little "hopper" of no mean ability, which also freely makes use of its wings when needful; an artful dodger, and an adept in all descriptions of tumbling and vaulting. While common wherever there is a thick and succulent growth of herbage, it is especially plentiful in the long grass and sedge of meadows, by the side of ditches, etc., becoming even abundant locally.

The season during which it may be procured in the adult state is probably the longest of all of our locusts; I have captured specimens from June 24 to Nov. I7. Not only is its season a protracted one but it is one of the most thoroughly distributed of our species in area, and can probably be found in every township of New England wherever there is a grassy area of some extent. About 700 specimens in my collection are from the following localities : Deering, Portland, Fryeburg, Hudson, (F. P. Briggs), Norway, and Speckled Mt., Stoneham, Me.; No. Conway, Kingston (S. W. Denton), Hanover (Prof. C. M. Weed), summit of Mt. Washington, N. H.; Hyde Park, Stowe, Montgomery, Jay, Newport, Hartland (Prof. C. M. Weed), Brattleboro (Mrs. J. B. Powers), Vt. ; Kingston, and Block Id., R. I. ; all quarters 
of Conn.; and various places in Mass., including Winchendon, Greylock Mt., Penikese, Cuttyhunk, and Martha's Vineyard Ids. The specimens from Greylock Mt. consist of both long and short winged adults and young, showing that the species undoubtedly breeds there; those from Speckled Mt. on the contrary are all long-winged adults and probably flew there, having been observed by $\mathrm{Mr}$. Scudder in the middle of Sebago Lake almost simultaneously. A notation and description by $\mathrm{Mr}$. Scudder of its song and attitude during stridulation will be found in Distribution of Insects in New Hampshire and the 23rd report of the Entomological Society of Ontario.

\section{A THYSANURAN OF THE GENUS ANOURA.}

BY F. L. HARVEY, ORONO, ME.

Prof. A. S. Packard in his "Syn. Thys. of Essex Co. Mass." p. 27 describes a species of Anoura under the name $A$. gibbosa, which was collected at Brunswick, Me. The description is so meagre and differs so materially from a form found in similar situations about Orono, Me., that we submit the following account of specimens examined.

Description.- Lead colored or pale indigo bluish. Body short and broad with broad segment. Head long in proportion to the other segments, and divided above into two areas: a wide anterior flattened portion, bearing three rounded tubercles. The middle one much larger and marked by about twenty small irregular color patches. The posterior portion narrower, ridged, bearing five tubercles, the middle one rectangular larger and two lobed by a transverse depression. The others small and rounded.

The prothorax bears four tubercles, the two median ones small or obsolete, the location indicated by hairs. The segments from the third to the eighth inclusive six-tuberculate. Ninth segment four tuberculate.
The body ending in two large tubercles. The tubercles armed with whitish hairs at the apex which become larger, longer and more numerous toward the posterior part of the body. The tubercles are colored like the body but surrounded at the base by a light colored ring which has light colored lines radiating from it to the apex of the tubercles breaking the color into six sub-triangular zones. The tubercles on the second segment are triangular at the base and the color broken by lighter lines into twelve irregular patches nine surrounding three. Body widest at 7 th to 8 th segments. The bucal cone acute, broad at the base, prominent and projecting beyond the head, as shown in Fig. 2. Antennae short, stout, hirsute, as long as half the width of the head. Basal joint broadest. Three basal joints about equal. Terminal joint longest, narrowest, conical, lighter colored.

Legs short and stout slightly longer than half width of body. Underside of body yellowish at the insertion of the legs.

Measurements.-Total $\mathrm{I} .9 \mathrm{~mm}$. to $\mathrm{I} .6 \mathrm{~mm}$. Greatest width .798 at 8 th seg., head, .399 $\mathrm{mm}$. long. Breadth $.532 \mathrm{~mm}$. behind but at base of antennae $.319 \mathrm{~mm}$. Antennae.2 $3 \mathrm{~mm}$. 

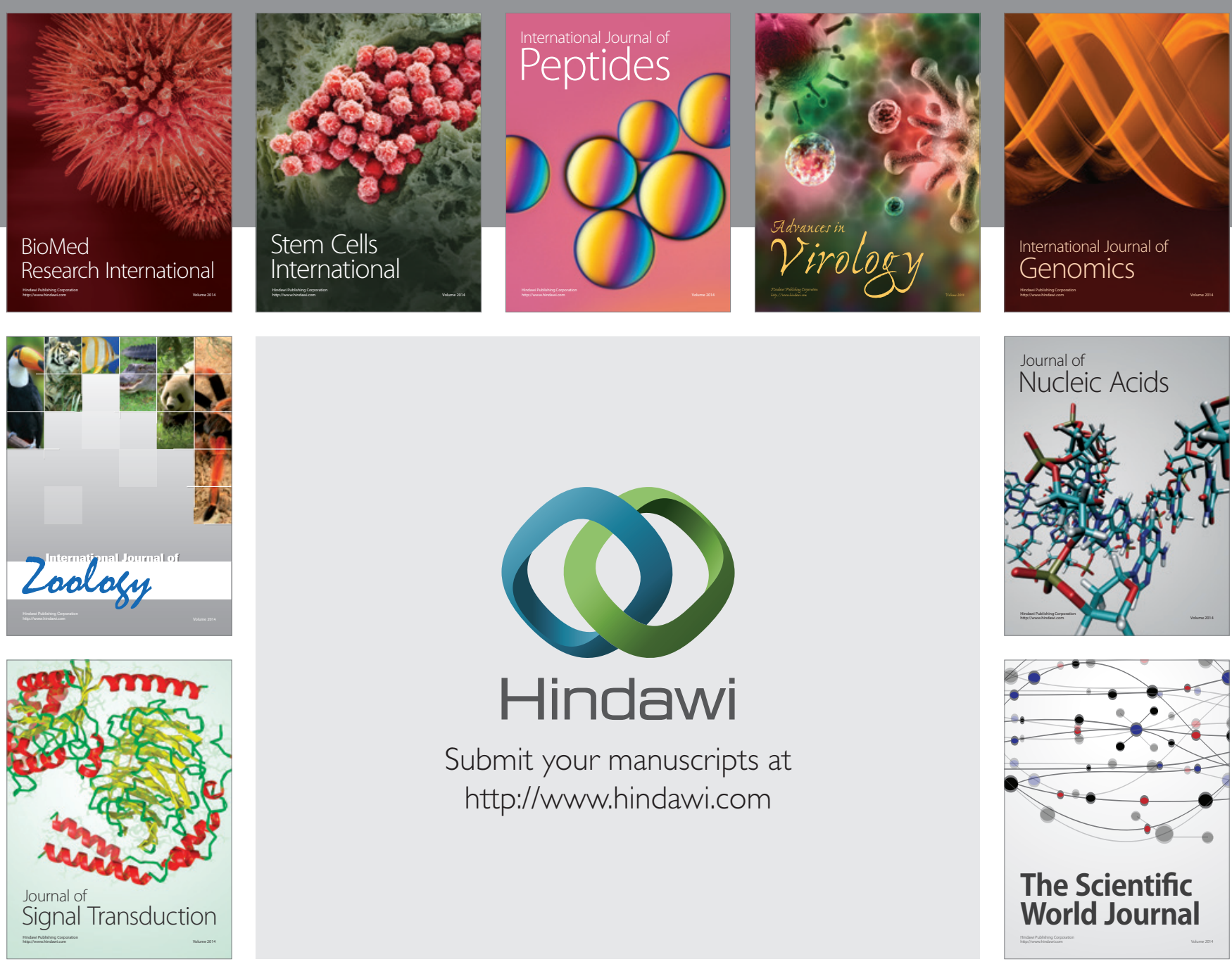

Submit your manuscripts at

http://www.hindawi.com
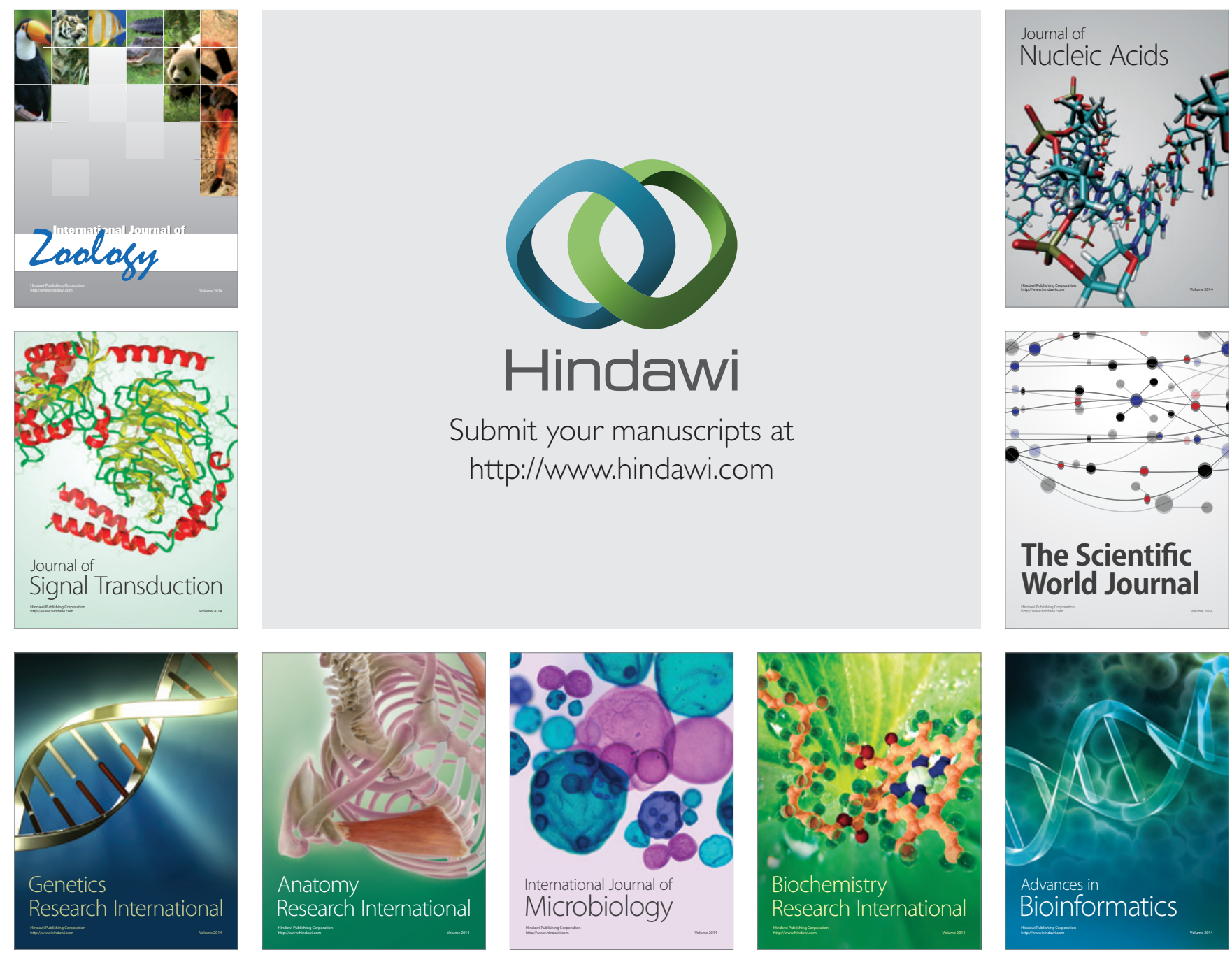

The Scientific World Journal
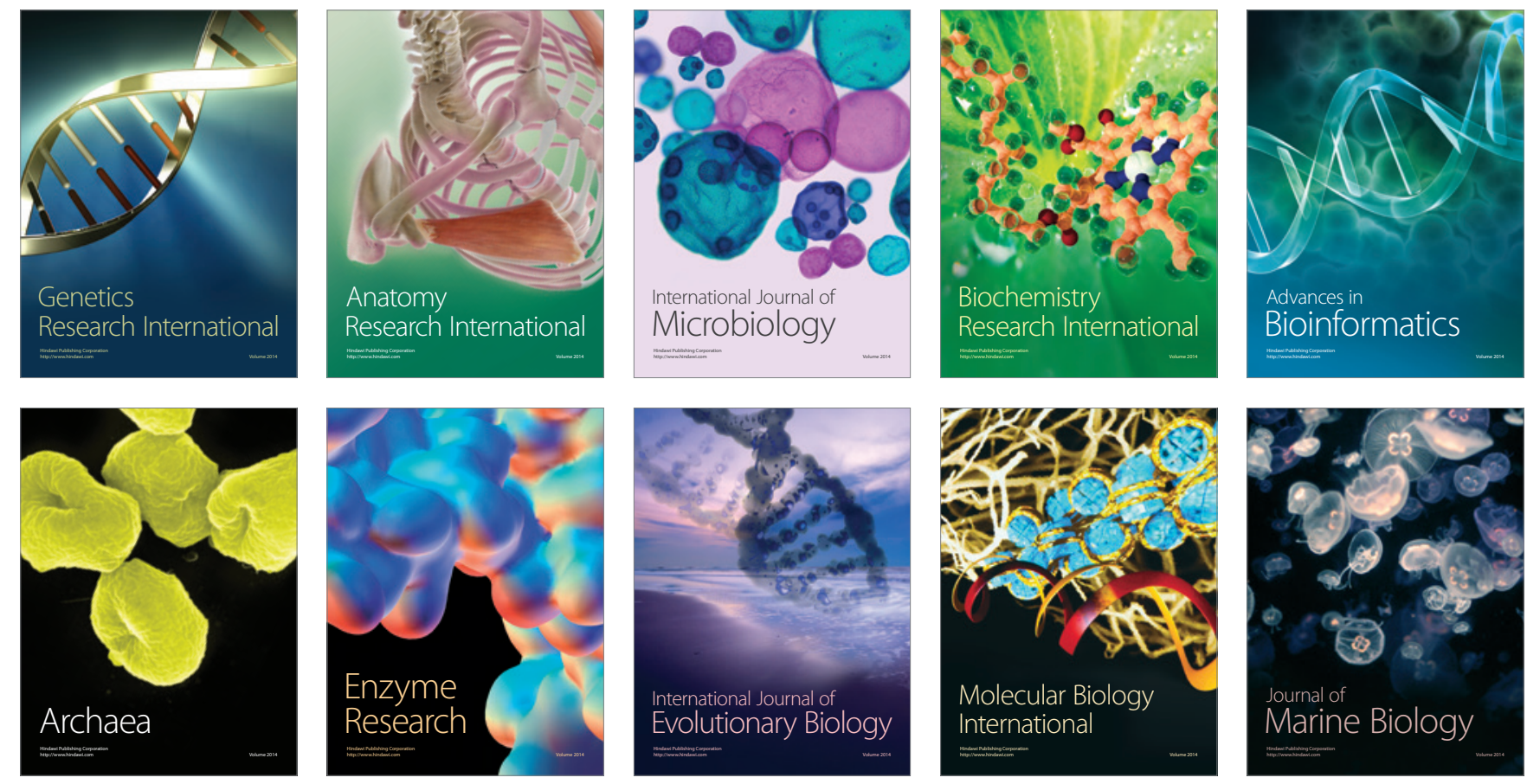